$$
\begin{aligned}
& \text { DP-MS-79-30 } \\
& \text { CONF - } 800305-1 \\
& \text { CONF-791112-- } 46
\end{aligned}
$$

\title{
CANISTER COMPATIBILITY WITH CARLSBAD SALT
}

\author{
W. N. Rankin, Author \\ To be presented by \\ J. R. Wiley
}

Savannah River Laboratory

E. I. du Pont de Nemours and Company

Aiken, South Carolina 29801

Proposed for presentation at

1979 Annual Meeting

Materials Research Society

Cambridge, Mass.

November $26-30,1979$

\section{MASTER}

This paper was prepared in connection with work under Contract No. AT(07-2)-1 with the U. S. Department of Energy. By acceptance of this paper, the publisher and/or recipient acknowledges the U.S. Government's right to retain a nonexclusive, royalty-free license in and to any copyright covering this paper, along with the right to reproduce and to authorize others to reproduce all or part of the copyrighted paper. 


\section{DISCLAIMER}

This report was prepared as an account of work sponsored by an agency of the United States Government. Neither the United States Government nor any agency Thereof, nor any of their employees, makes any warranty, express or implied, or assumes any legal liability or responsibility for the accuracy, completeness, or usefulness of any information, apparatus, product, or process disclosed, or represents that its use would not infringe privately owned rights. Reference herein to any specific commercial product, process, or service by trade name, trademark, manufacturer, or otherwise does not necessarily constitute or imply its endorsement, recommendation, or favoring by the United States Government or any agency thereof. The views and opinions of authors expressed herein do not necessarily state or reflect those of the United States Government or any agency thereof. 


\section{DISCLAIMER}

Portions of this document may be illegible in electronic image products. Images are produced from the best available original document. 
CANISTER COMPATIBILITY WITH CARLSBAD SALT

W. N. Rankin, author

To be presented by J. R. Wiley

Savannah River Laboratory

E. I. du Pont de Nemours and Company

Aiken, South Carolina 29801

\section{INTRODUCTION}

This paper describes the results of the examination of candidate canister alloy specimens heated with Carlsbad salt in sealed capsules for up to 5000 hours and in unsealed capsules for up to 10,000 hours. The compatibility of candidate alloys, for use in fabricating canisters for solidified radioactive waste, with salt from a potential final storage location for waste forms is being evaluated by long-term heating tests.l In these tests, canister alloys are being exposed to salt in a manner simflar to that expected during final storage of canisters of solidified waste forms in a salt deposit. Test specimens are being heated at the temperature expected during waste form storage and at higher temperatures to accelerate any reactions that may occur. Reaction rates are determined by examining replicate specimens periodically removed from the test.

\section{SUMMARY}

No significant reaction was found when candidate canister alloys were heated with salt from Carlsbad, New Mexico, for up to 5000 hours in sealed capsules and for up to 10,000 hours in unsealed capsules at temperatures $\left(80\right.$ to $225^{\circ} \mathrm{C}$ ) that bracket the maximum temperature calculated for reference Savannah R1ver Plant (SRP) waste containers at 20-foot spacings in salt. ${ }^{2}$ Additional tests were madc at $600^{\circ} \mathrm{C}$ in sealed capsules to charactertze reactions that may occur between candldate canister alloys and any component of the salt that is released when decrepitation occurs. Under these extreme conditions there was no significant attack of Type 304L stainless steel. But, there was up to 20-mils attack of the low-carbon steel. 
DISCUSSION

Materials Used in Tests

Candidate Canister Alloys. Canister alloys for these tests were chosen for testing because of their oxidation resistance, low temperature ductility, and cost. Cor-Ten A (Cor-Ten is a trademark of U.S. Steel Company) is a low-alloy steel containing $1 \%$ chromium, $0.5 \%$ nickel, and $0.35 \%$ copper. Th1s alloy costs only a little more than low-carbon steel, but it has better resistance to air oxidation.

ASTM-A-516 (Grade 70) covers a low-carbon steel plate that is suitable for use at low temperatures because of its low nilductility transition temperature (NDTT). This specification could be important if low-carbon steel is considered for use as the outer canister ${ }^{3}$ and low-temperature impact resistance is required as it is in the case of shipping casks for radioactive material. 4

Past experience indicates that low-carbon and low-alloy steels have similar compatibility with vitrified waste. Therefore, the behavior of these two alloys should be representative of any other similar steels that might be slected. 1

Type 304L stainless steel has better resistance to air oxidation than either Cor-Ten A or low-carbon steel [ASTM-A-516 (Grade 70)]. It is more resistant than either of these alloys to accelerated corrosion in a radiation field. In a radiation field nitrogen combines with the oxygen and water vapor in the air to form nitric acid. But, stainless steel costs about three times more than the other alloys. It might not be suitable for final storage in salt because of its susceptibility to chloride pitting and/or stress corrosion cracking.

Carlsbad Salt. The salt used in these tests was from a section of core from Drill Hole AEC-8 in Carlsbad, New Mexico. The core, four inches in diameter and three feet long, was taken from the depth of 2142.7 to 2145.3 feet. Carlsbad is a potential final storage site for canisters of solidified radioactive waste and is being studied in the Waste Isolation Pilot Plant Program.5, 6

The salt is primarily halite $(\mathrm{NaCl}) .7$ When this salt was crushed, it gave off a faint odor suggestive of hydrogen sulfide. But, hydrogen sulfide was not confirmed by analyses of the salt.

As in most bedded (stratified) salt, 8 moisture is trapped in small pockets on the grain boundaries and within the grains. When the salt is heated to around $250^{\circ} \mathrm{C}$, the steam pressure in these pockets becomes greater than the bonding forces. This results in the salt fracturing with considerable violence. This 
phenomenon, known as decrepitation, results in release of water

vapor and hydrogen sulfide.

\section{Experimental Procedure}

Two types of specimens are being used in these tests (1) unsealed capsules and (2) sealed capsules.

Unsealed Capsules. The first generation compatibility tests were started in unsealed capsules (Figure 1). Small capsules of Cor-Ten A and Type 304L stainless steel were tested. Low-carbon steel meeting specification ASTM-A-516 (Grade 70) was not used in these tests. These tests were started before the decision was made to test a material with properties meeting the low NDTT specification required for materials used in the construction of qualified shipping containers for radioactive material. In these tests the capsules were filled with crushed salt. The capsules were then covered, but not sealed, and placed in holes drilled in a solid piece of this salt. The entire assembly (salt block and capsule) was wrapped in aluminum foil in an attempt to confine any gases, such as hydrogen sulfide, or water vapor that might be present in the salt and that could influence the attack of the metal.

Unsealed capsules are being heated for up to 50,000 hours at $80^{\circ} \mathrm{C}$, a reasonable temperature expected during waste form storage, and also at $225^{\circ} \mathrm{C}$ to accelerate any reactions that might occur. The maximum temperature of tests in unsealed capsules is limited to $225^{\circ} \mathrm{C}$ because the salt decrepitates at about $250^{\circ} \mathrm{C}$. Decrepitation destroys this type of test assembly.

Sealed Capsules. The second series of compatibility tests were started in sealed capsules (Figure 2). Small right circular cylinders of low-carbon steel ASTM-A-516 (Grade 70), or Type 304L stainless steel were partially embedded in a small block of salt. This assembly was then put inside a capsule made of Type 304L stainless steel high-pressure pipe fittings. The capsules were sealed by tungsten-inert-gas (TIS) welding. These tests are desigued to characterize reactions that occur between the canister alloys and any volatile components of the salt. Reaction of the portion of the specimen embedded in the salt will be indicative of the compatibility between the canister alloy and solid salt and vapor from the salt. Reaction of the portion of the specimen exposed only to the vapors from the salt will isolate the effect of the salt vapor above.

Specimens in sealed capsules are being heated for up to 50,000 hours at 80,225 , and $600^{\circ} \mathrm{C}$. The amount of attack of the specimens heated in sealed capsules at 80 and $225^{\circ} \mathrm{C}$ will be compared with the amount of attack of specimens heated in unsealed capsules at these temperatures. 


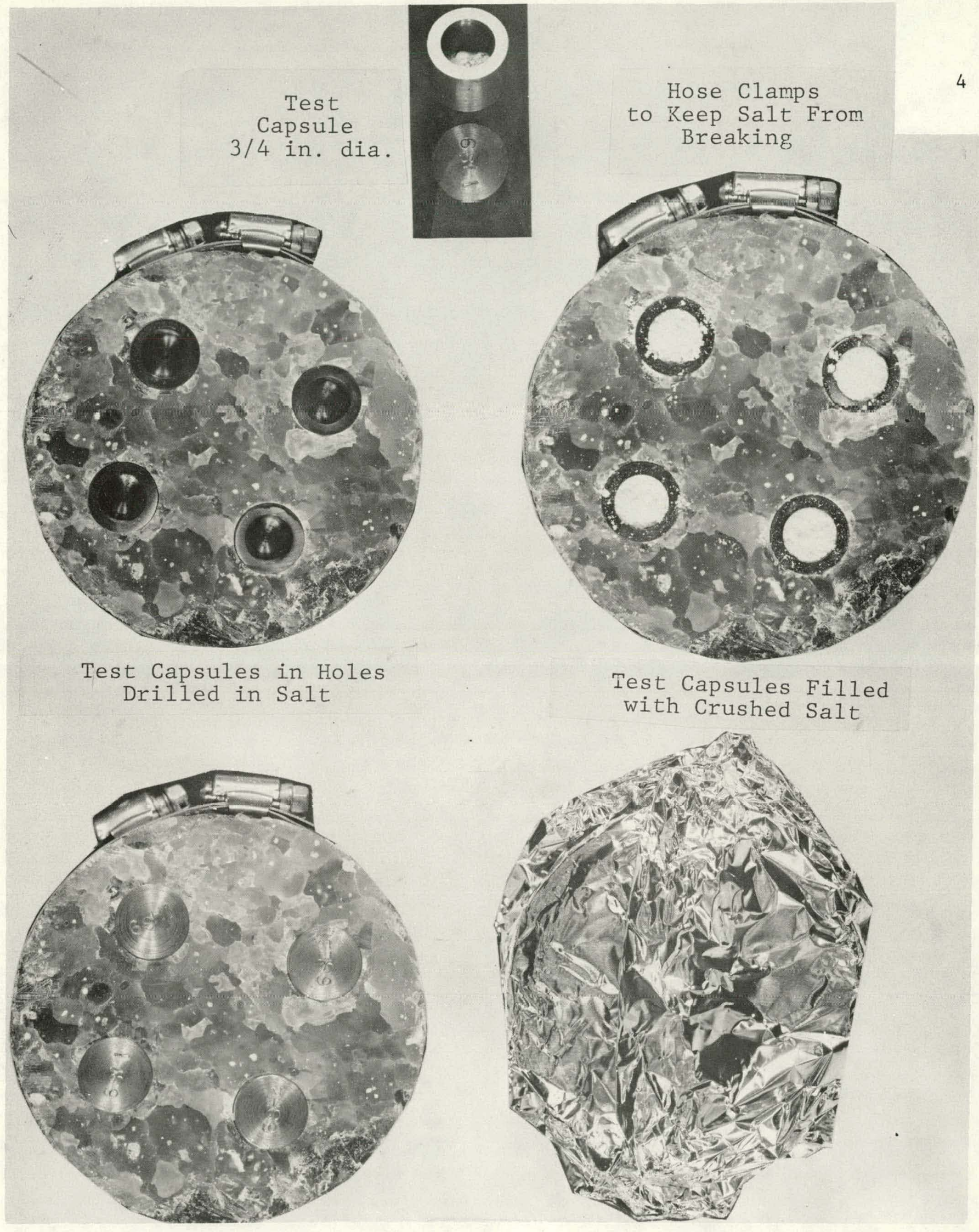

Fig. 1. Unsealed Capsule Assembly 


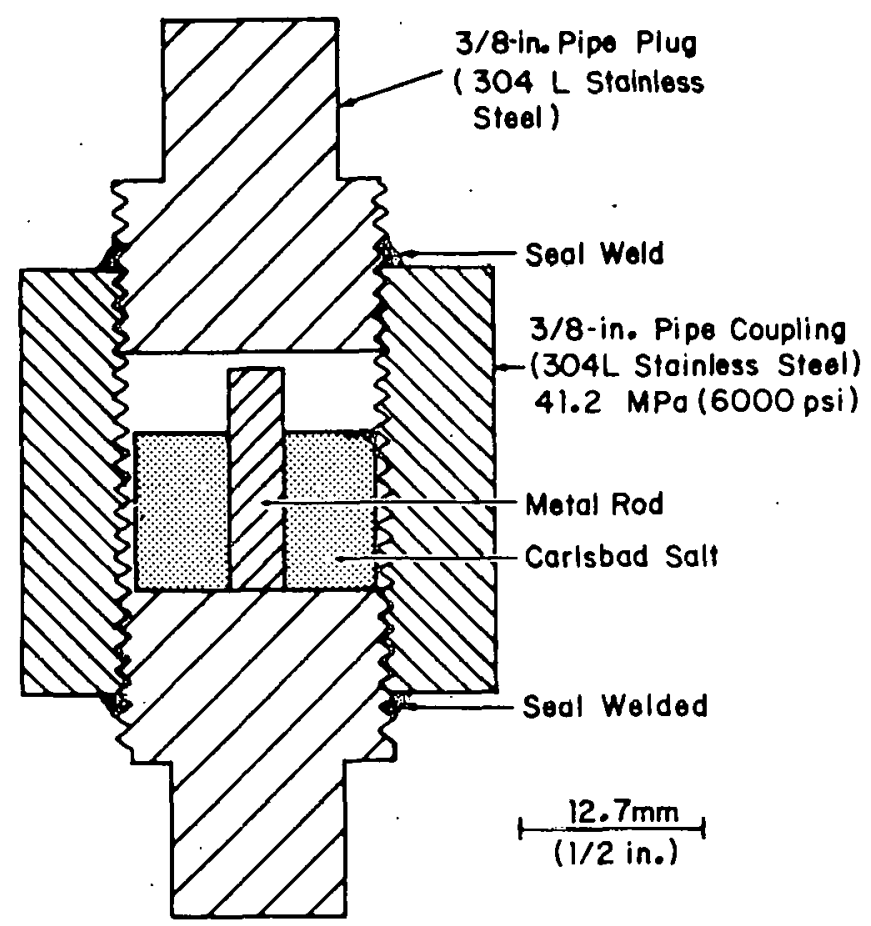

Fig. 2. Sealed Capsule As sembly

Tests at $600^{\circ} \mathrm{C}$ in sealed capsules were included in the test matrix to characterize any reactions that may occur between candidate canister alloys and any component of the salt that is released when decrepitation of the salt occurs. Decrepitation of the salt at about $250^{\circ} \mathrm{C}$ will occur, but this will not destroy the test assembly, as in the case of the unsealed capsules. The salt, the metal specimen, and any material that is released from the salt by decrepitation will remain in contact with the specimen inside the capsule.

Resulto

Unsealed Capsules. After the unsealed capsules had been heated for 10,000 hours, they were removed from the block of salt, the powdered salt was poured out of the capsules, and the surfaces of the capsules were examined visually and at low magnifications. There was no significant change in the appearance of the capsules heated at $80^{\circ} \mathrm{C}$ for 10,000 hours and the appearance nf replicate specimens heated 1000 hours examined previously.9. Corrosion producte and some pieces of salt adhered to the $O D$ and ID surfaces of the Type $304 \mathrm{~L}$ stainless steel capsule heated at $225^{\circ} \mathrm{C}$ for 10,000 hours. There was more corrosion products on the OD surface of the capsule than on the ID surface. 
The dimensions of the unsealed capsules before and after

heating were $<5 \mathrm{mils}$ which is within the experimental error of the technique used.

A cross section through capsules heated at $225^{\circ} \mathrm{C}$ was examined on the optical microscope and the scanning electron microscope (SEM). Very little attack was found of the Type $304 \mathrm{~L}$ stainless steel capsule heated 10,000 hours at $225^{\circ} \mathrm{C}$. No oxide film was found on the OD surface. Patches of oxide only 0.1 mil thick were found on the ID surface.

The ID surface of the low-carbon steel capsule heated 10,000 hours at $225^{\circ} \mathrm{C}$ was attacked less than the OD surface. An oxide film 0.6 mil thick was found on the OD surface. An oxide film 0.3 mil thick was found on the ID surface.

The capsules heated at $80^{\circ} \mathrm{C}$ were not examined on the microscope because no significant attack was found of capsules heated at $225^{\circ} \mathrm{C} .9$

Sealed Capsules. The sealed capsules were opened by machining through the wall from the OD to the ID using a vertical milling machine. The capsule was not rotated so that damage to the salt and the specimen would be minimized.

The specimens heated at 80 and $225^{\circ} \mathrm{C}$ were pulled out of the block of salt with tweezers. The Type 304L stainless steel specimens showed no visible sign of oxidation. They had the same appearance as recently machined specimens. The low-carbon steel specimens were covered, with a black oxide film. There was no difference in the appearance of either the end of the specimen exposed to the vapor or the end of the specimen in the hole in the block of salt.

The specimens heated at $600^{\circ} \mathrm{C}$ could not be pulled out of the fractured block of salt with pliers. The pieces of salt were chipped away with a 8 mall pick. Both ende of the Type 30/L etain= less steel specimen were covered with a thin black oxide film. But, no salt adhered to the specimen. The end of the low-carbon steel exposed to vapor was covered with a thick black film. Salt was bonded to the oxide on the end of the specimen in the salt.

No significant changes in dimensions occurred to specimens in test at conditione expected during waste form etorage. Changec in diameter were <2 mils for Type 304L stainless steel and low-carbon steel specimens heated for up to 5000 hours at the temperature expected during waste form storage $\left(80^{\circ} \mathrm{C}\right)$ and at a higher temperature $\left(225^{\circ} \mathrm{C}\right)$ to accelerate any reactions that might occur. 
In specimens exposed to more extreme conditions $\left(600^{\circ} \mathrm{C}\right)$,

there was no significant attack of Type 304L stainless steel in 5000 hours. But, extensive attack of the low-carbon steel occurred. The end of the specimen exposed to the vapor was attacked 20 mils in 5000 hours. The end of the specimen embedded in the salt was attacked 9 mills in 5000 hours.

The attack of the low-carbon steel specimen heated for 5000 hours with Carlsbad salt in a sealed capsule was characterized. $X$-ray diffraction analysis was performed on a piece of material from the surface of the portion of the specimen exposed to vapor. A longitudinal section through the entire specimen and transverse sections through each end of the specimen were examined on the SEM.

The appearance of the layers of material on both ends of the specimen indicate that the mechanism of attack of both ends was similar (Figure 3 ). There was about 0.8 mil of intergranular penetration of the low-carbon steel specimen. On the grain boundaries there was a material which contained iron and sulfur. Adjacent to the metal was a layer of material composed of the same elements as the low-carbon steel. This material was identifled by $x$-ray diffraction analysis as iron oxide. The iron oxide layer was covered with a layer composed of iron oxide and a small amount of iron sulphide. Some particles of salt were embedded in this layer on the end of the specimen embedded in the salt.

A mechanism of accelerated corrosion could possibly be taking part in the oxidation of the low-carbon steel specimens in sealed capsules with Carlshad salt at $600^{\circ} \mathrm{C}$. Normally this reaction is associated with atmospheric corrosion in urban and industrial districts because of the presence of sulphur dioxide produced by the burning of fuel.10,11 First, the hydrogen sulfide from the decrepitated salt would react with the air inside the sealed capsule to form $\mathrm{SO}_{3}$. The $\mathrm{SO}_{3}$ would react with the water vapor from the salt forming $\mathrm{H}_{2} \mathrm{SO}_{4}$. The oxidation reaction of $\mathrm{H}_{2} \mathrm{SO}_{4}$ with the cannister alloy liberates $\mathrm{SO}_{3}$. This could lead to a cyclical series of reactions with iron where the reaction products are hydrated Iron oxide and morc sulfuric acid. This mechanism is consistent with the SEM, $x$-ray energy spectrometry (XES), and $x$-ray diffraction analysis of the films on the sample which showed that the specimen was covered with a layer of iron oxide and a layer of iron sulphide.

\section{APPLICATION OF RESULTS}

The results of these tests at 80 and $225^{\circ} \mathrm{C}$ show that there is no significant attack of Typc 304L stainless steel or luw-carbun steel under conditions expected during waste form storage and at a higher temperature designed to accelerate any reactions that might 


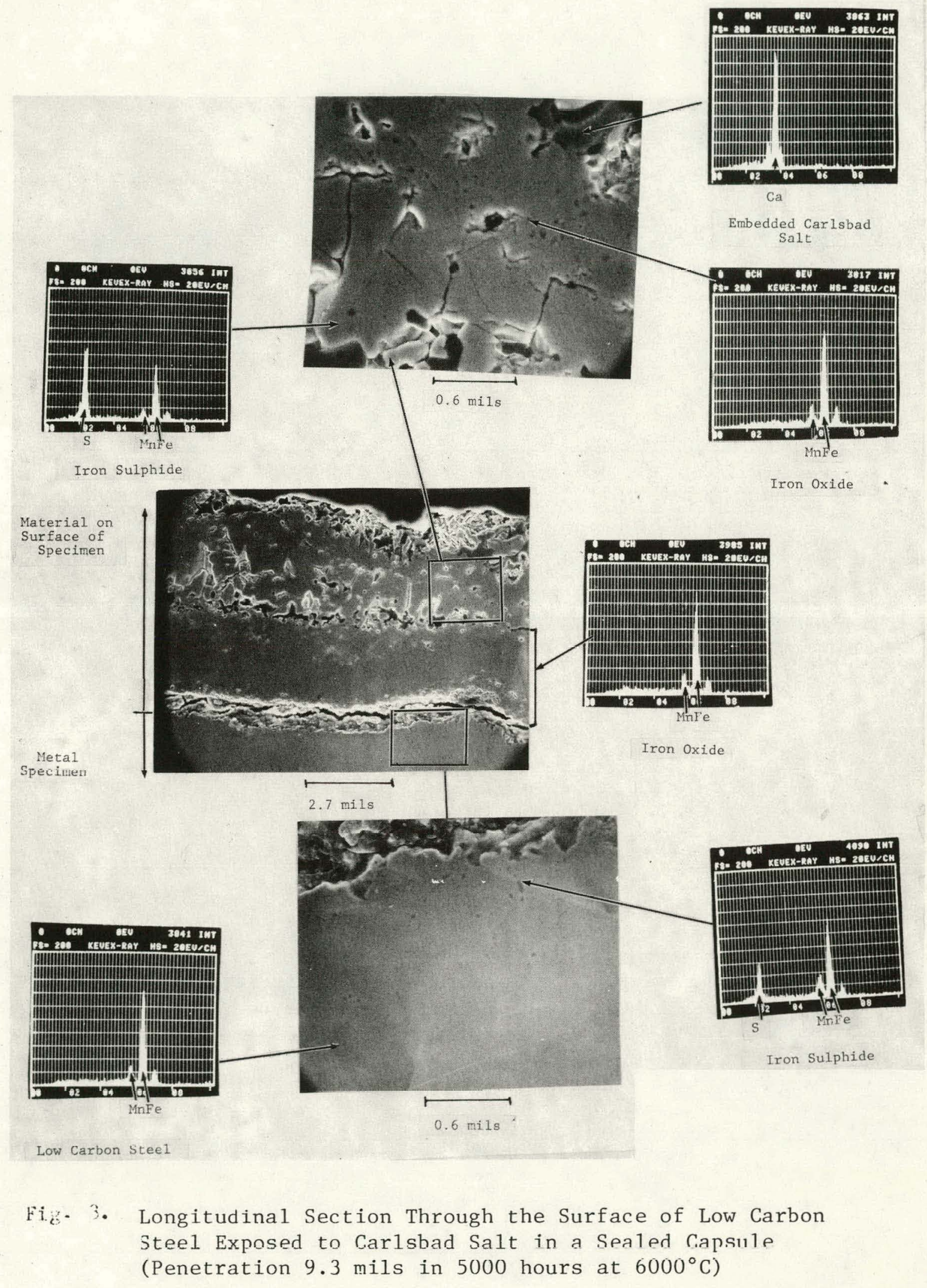


occur. The results of the tests at $600^{\circ} \mathrm{C}$ show that there is no significant attack of Type $304 \mathrm{~L}$ stainless steel at this temperature by the volatile products of the salt released by decrepitation. But, there was extensive attack of the low-carbon steel under these extreme conditions. Storage conditions are expected to be designed to prevent temperatures high enough to cause decrepitation from occurring. However, because the canister of waste will be a higher temperature than the surrounding salt, the moisture trapped in small pockets on the grain boundaries and within the grains of the salt can migrate to the waste form during storage. 12 In addition, movement of this material may perhaps be enhanced by movement of the salt by creep to close in the space surrounding the waste form. Creep of the salt will occur because of the pressure of the overburden at this depth.

\section{ACKNOWLEDGMENTS}

The author is grateful to D. W. Powers of Sandia Laboratories for supplying the salt. He is also indebted to G. G. Wicks of Savannah River Laboratory (SRL) for the X-ray Diffraction Analysis and to J. A. Donovan formerly of SRL and P. K. Smith of SRL for their helpful discussions.

Work was done under USDOE Contract AT(07-2)-1.

\section{REFERENCES}

1. W. N. Rankin, "Compatibility Testing of Vitrified Waste Forms." Presented at Corrosion/78, Houston, Texas, March 6-10, 1978. National Association of Corrosion Engineers, Houston, TX.

2. M. H. Tennant, "Temperatures Generated by Underground Storage of Defense Waste Canisters." To be presented at Corrosion/80, Houston, Texas, March 6-10, 1980. National Association of Corrosion Engineers, Houston, TX.

3. A. S. Jennings, "P1ans for Solidification of Savannah River Plant lligh Level Wastes." Presented at the 70th Annual AIChE Meeting on Long-Term Management of Defense High-Level Waste, November 15, 1977, American Institute of Chemical Engineers, New York, NY.

4. L. B. Shappert, Cask Designers Gulde. USERDA Report ORNLNSIC-68, Oak Ridge National Laboratory, Oak Ridge, TN (1970).

5. WIPP Conceptual Design Report. SAND 77-0274 (Part I and II), Sandia Laboratories, Albuquerque, NM (1977). 
6. J. W. Braithwaite and M. A. Molecke, "High-Level Waste Canister Corrosion Studies Pertinent to Geological Isolation." Proceedings of Conference on High-Level Solid Radioactive Wastes, NUREG CP-0005, NRC, Denver, CO (1979).

7. M. A. Molecke, Personal Communication, Sandia Laboratories, Albuquerque, NM (October 1976).

8. R. L. Bradaham and W. C. McClain, Editors, Project Salt Vault: A Demonstration of the Disposal of High-Activity Solidified Wastes in Underground Salt Mines. ORNL-4555, UC-70 - Waste Disposal and Processing, Oak Ridge National Laboratory, Oak Ridge, TN (April 1971).

9. Savannah River Laboratory Quarterly Report, Waste Management. DPST-77-125-2 (Apri1-June 1977).

10. J. C. Scully, The Fundamentals of Corrosion. Second Edition, Pergamon Press, New York, NY (1975).

11. U. R. Evans and C. A. J. Taylor, "Mechanism of Atmospheric Rusting." Corrosion Science, Volume 12, pp. 227-246 (1972).

12. Executive Summary for Technical Support for GEIS: Radioactive Waste Isolation in Geological Formations. Y/OWI/TM36/1, Science Applications Incorporated, Oak Ridge, TN (1978). 